\title{
ANALYSIS OF ECONOMIC RESULTS OF DIETARY MEDICINAL PLANTS USAGE IN BROILERS PRODUCTION
}

\author{
Nikola Puvača ${ }^{1}$, Svetlana Roljević Nikolić ${ }^{2}$, Almir Muhović3 \\ *Corresponding authorE-mail: svetlana_r@iep.bg.ac.rs
}

\begin{abstract}
A R T I C LE IN F O
A B S T R A C T

Original Article

Received: 01 June 2021

Poultry meat production represents one of the most inten-

Accepted: 09 November 2021

sive production in poultry fattening. Broiler's production lasts on average 42 days, which enables quicker income of the employed resources. With the ban of dietary antibiotics doi:10.5937/ekoPolj2104977P

UDC 636.52/.58:636.084.42 usage in poultry meat production, new natural feed additives had to been engaged. This research aimed to investigate the effects of medicinal plants addition to broiler rations on the

Keywords:

economic results, financial analysis, meat production, medicinal plants economic results of the production. Our results have reviled significantly $(p<0.05)$ positive effects. Chickens on medicinal plants (T1) addition have recoded much higher total benefit at the end of production (698.1 $€$ ) than chickens on control (T2) treatment (335.6€). Following the same tendency, the benefit per chicken was also higher in medicinal JEL: Q12, Q14 plant treatment $(0.15: 0.07 €)$ and profitability (8.01:3.59\%). Upon the gained results, it can be assumed that usage of dietary, medicinal plants expresses a beneficial effect on the monitored economic parameters compared to broilers fed with commercial compound mixtures.
\end{abstract}

(C) 2021 EA. All rights reserved.

\section{Introduction}

Over the last few years, medicinal plants as dietary supplement prices have been reduced primarily because of many competitors appearing in the marketplace (Puvača et al., 2020). Nevertheless, in long run, we can predict that the price of main nutrients sources used in daily animal nutrition stays high (Popović et al., 2018). In order to enhance poultry performance in the future additional endeavors will be needed

1 Nikola Puvača, Ph.D., Associate Professor and Research Associate, Faculty of Economics and Engineering Management in Novi Sad, University Business Academy in Novi Sad, Cvećarska 2, 21000 Novi Sad, Serbia, E-mail: nikola.puvaca@fimek.edu.rs, ORCID ID (https://orcid.org/0000-0002-5500-7010)

2 Svetlana Roljević Nikolić, Ph.D., Senior Research Associate, Institute of Agricultural Economics, Volgina Street no. 15, 11060 Belgrade, Serbia, E-mail: svetlana_r@iep.bg.ac. rs, ORCID ID (https://orcid.org/0000-0002-3139-0289)

3 Almir Muhović, Ph.D., Research Associate, Institute for Vegetable Crops Smederevska Palanka, Karadjordjeva 71, 11420 Smederevska Palanka, Serbia, E-mail: muhovic@ institut-palanka.rs, ORCID ID (https://orcid.org/0000-0003-1479-2654)

http://ea.bg.ac.rs 
to indorse production, health, and welfare (Puvača et al., 2016). In the last decade, there is a strong tension towards the usage of antibiotics in animal production and their reduction in order to avoid antimicrobial resistance and emergence of harmful pathogens which is in the correlations with consumer's safety (Reisch et al., 2013). These issues include the return of each element in the trade group concerning animal production at the same time as continuing to focus on consumer needs (Croxton et al., 2001). All these difficult circumstances are not easy to achieve. It is important to enhance that economic and social breadth, besides productivity in the production chain represents a serious problem (Ćirić et al., 2015; Lovarelli et al., 2020; Tasić, 2018). Nowadays in the EU economical frame, the greatest obstacle in the development presents a production of positive financial results, and the producers are faced to search their way out for longstanding continued existence (Kuckertz et al., 2020). There have been several proposed solutions over the years for fixing the burning problem of dietary performance optimization, but the only successful solution proposed are multi-level (Guo et al., 2020). Based on all mentioned, it is necessary to propose a new nutritional concept as soon as possible.

Usage of dietary approaches to enhance the quality of the final product for human consumption such as meat is a comparatively innovative method which appeared in the last years (Woods et al., 2020). Latest it has been scientifically proven that dietary approaches represent a valuable solution in the improvement of meat quality (Cardoso-Ugarte \& Sosa-Morales, 2021). The quality of meat is significant because broiler meat is often consumed as separate parts of whole carcass rather than as whole carcasses (Puvača et al., 2018). The most important parameters of broiler meat quality include $\mathrm{pH}$ and color. Reduce of $\mathrm{pH}$ in muscle is related to the most important parameter of meat quality. Precipitous reduction of $\mathrm{pH}$ in meat leads to a pale, soft, and exudative meat with decreased water holding capacity (Baldi et al., 2021).

Over the years, dietary antibiotics in poultry production have served as an excellent tool for growth promotion and prevention of disease (Puvača \& de Llanos Frutos, 2021). However, since of the bio-security pressures for population health, which come from mounting resistance of pathogens to antibiotics, there is a worldwide necessity for removal of antibiotics from poultry nutrition. The poultry industry's intensive broiler production sector is eager to maximize performance and reduce economic losses caused by the removal of antimicrobial growth promoters, as well as to guarantee the safety of broiler meat through the control or elimination of foodborne infections (Andleeb et al., 2020). In several scientific studies, the positive potential of different microorganisms and bioactive substances in improving animal performance and health has been emphasized (Misra et al., 2021). Illustrations involve mainly natural alternatives such as probiotics, organic acids, enzymes, and medicinal plants. The majority of medicinal plants' beneficial effects are derived from their bioactive molecules. The natural activities of medicinal plants constitute are well recorded, as are their other essential roles, as many other beneficial properties. At the moment, there is a growing concern about natural products used 
in poultry daily diets (Aćimović et al., 2020). Medicinal plants, herbs, and spices are listed among the most researched natural additives in poultry nutrition, not only in powder form or as essential oils extracts but also as homogenized multiple forms (Popović et al., 2018).

This paper aimed to determine the effects of medicinal plants and on the economic aspects of broilers.

\section{Materials and methods}

Firstly, the biological experiment was performed on a 10,000 broiler chickens. Chickens were distributed on two dietary groups (T1 and T2) and fed under the same conditions. Broilers were fed with the addition of medicinal plants mixture in concertation of $1 \%$ (T1), and with a commercial feed mixture as a control treatment (T2). Broiler's productions lasted 42 days. A floor fattening system was used, and environmental conditions were following Hubbard hybrid specifications. Estimate of the cost for feed mixtures has been obtained giving to the requirement of expenditures for the formulation of compound feed mixtures. The expenditure for other resources has been determined giving to the expenditure made on the experimental farm following the sell prices in the marketplace. Assets into infrastructures and equipment have been determined based on basic assets. Fees for wages were determined following realized expenditures. Expenditures for the energy utilization were determined based on the realized expenditure of the fossil fuel and electric energy. An estimate of the revenue was established on the interpretation of revenue from the production, where the economic result gives the revenue from the complete poultry production.

\section{Results and Discussions}

The leading production indicators are given in Table 1. From the data presented in the given table and Figure 1, minor feed expenditure with the dietary addition of medicinal plants can be seen. Increased chickens' weight was also noticed at the end of 42 day fattening period in treatment T1, compared with treatment T2. The difference in the final body weight of chickens was statistically significant $(\mathrm{p}<0.05)$.

Evaluation of total financial values of broiler chickens eg., meat production begins with the evaluation of venture into the objects for rearing with all associated equipment. The investment into the broilers' production objects and equipment amount is approximately 70,000€. An estimate of other expenses such as human labor used energy, and additional materials have been obtained for each production cycle of broiler chickens. The allocation was divided evenly to the starting number of broilers bring to the farm, e.g., two equal dietary treatments. 
Table 1. Basic production results (Cost per unit, €)

\begin{tabular}{|l|r|r|r|r|}
\hline \multirow{2}{*}{ Category } & \multicolumn{4}{|c|}{ Dietary treatments } \\
\cline { 2 - 5 } & \multicolumn{2}{|c|}{ T1 } & \multicolumn{2}{c|}{ T2 } \\
\cline { 2 - 5 } & \multicolumn{2}{|c|}{ Units / Cost, $€$} & 5,000 & 0.38 \\
\hline Broilers & 5,000 & 0.38 & 4,935 & 1.40 \\
\hline Produced broilers & 4,800 & 1.40 & 6,909 & $9,672.6$ \\
\hline Produced broilers $(\mathrm{kg})$ & 6,720 & $9,408.0$ & 2.55 & \\
\hline Kg/Broilers & 2.31 & & $12,584.3$ & \\
\hline Total feed consumption $(\mathrm{kg})$ & 11,088 & & $2,368.8$ & 0.40 \\
\hline Starter $(\mathrm{kg})$ & 2,112 & 0.40 & $11,350.5$ & 0.38 \\
\hline Grover $(\mathrm{kg})$ & 10,800 & 0.38 & $7,106.4$ & 0.36 \\
\hline Finisher $(\mathrm{kg})$ & 6,192 & 0.36 & 1.8 & \\
\hline Feed conversion ratio $(\mathrm{kg} / \mathrm{kg})$ & 2.1 & & & \\
\hline
\end{tabular}

Total basic production cost has been shown in Figure 1, while obtained estimates established of the expenditure and the cost of the fattening chicken have been presented in Table 2 .

Figure 1. Total basic production cost, $€$

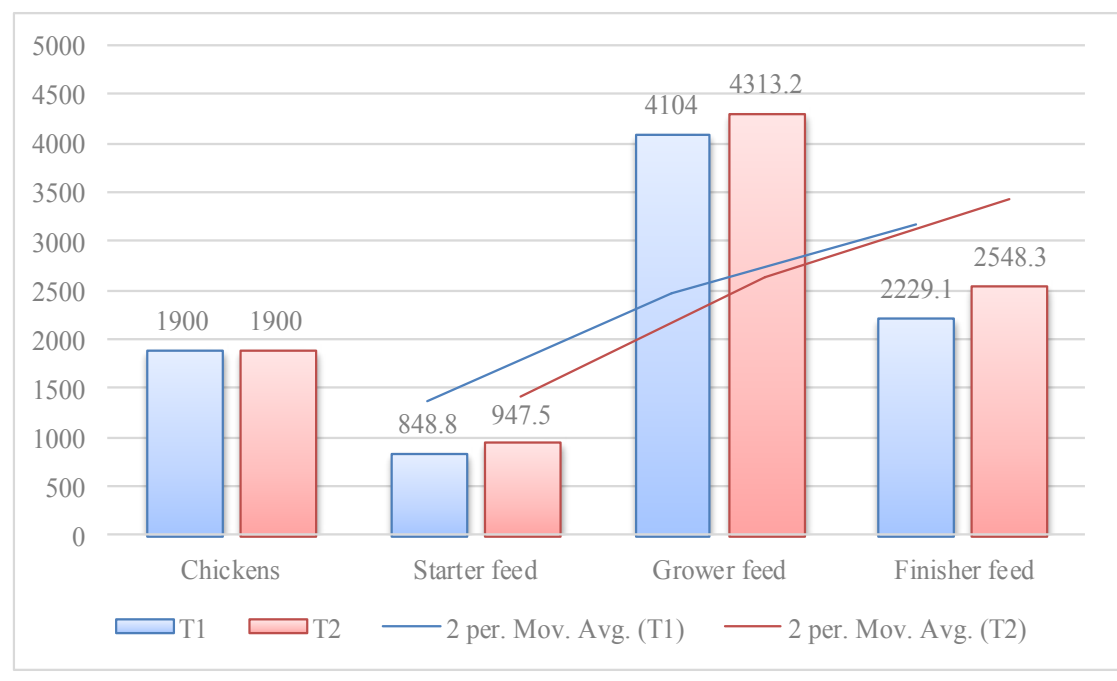

Source: Authors' calculations

Table 2. Calculation of the total expenses, $€$

\begin{tabular}{|c|c|c|}
\hline \multirow{2}{*}{ Category } & \multicolumn{2}{|c|}{ Dietary treatments } \\
\hline & T1 & T2 \\
\hline Feed & $7,181.9$ & $7,809.0$ \\
\hline Amortization & 700.0 & 700.0 \\
\hline Salaries & 400.0 & 400.0 \\
\hline Energy & 378.0 & 378.0 \\
\hline Additional materials & 50.0 & 50.0 \\
\hline Total & $8,709.9$ & $9,337.0$ \\
\hline
\end{tabular}


The income was calculated, including the incomes which farm was achieved based on the sale of chickens. The price for the chickens on $42^{\text {nd }}$ day of the fattening period was $1.40 € / \mathrm{kg}$. Following the number of fattened broilers and the selling amount, the estimations of the total revenue was made. Observed revenue was $9498.0 €$ for the group fed a diet with dietary addition of medicinal plants and $9672.6 €$ for the control treatment of chickens. The gain was determined as a discrepancy among the revenue and expenditure (Table 3). The benefit achieved per one productive cycle was $698.1 €$ for the chickens in treatment with the addition of medicinal plants and $335.6 €$ for the control treatment, e.g., $0.15 €$ and $0.07 €$ per produced broiler. If the realized gain is determined per kilogram of produced broilers, $0.05 € / \mathrm{kg}$ was achieved in the control treatment and $0.10 € / \mathrm{kg}$ in the treatment with dietary addition of medicinal plants $\mathrm{T} 1$. The economy determined from the ratio of total revenue and total expenditures were 1.08 (T1) and 1.04 (T2).

Table 3. Cost-effectiveness calculation of production, $\%$

\begin{tabular}{|l|r|r|}
\hline \multirow{2}{*}{\multicolumn{1}{c|}{ Indicators }} & \multicolumn{2}{|c|}{ Dietary treatments } \\
\cline { 2 - 4 } & \multicolumn{2}{|c|}{ T1 } \\
\hline Total expenses & $8,709.9$ & $9,337.0$ \\
\hline Total income & $9,408.0$ & $9,672.6$ \\
\hline Benefit & 698.1 & 335.6 \\
\hline Benefit per broiler & 0.15 & 0.07 \\
\hline Benefit per kg & 0.10 & 0.05 \\
\hline Economy & 1.08 & 1.04 \\
\hline Profitability, \% & 8.01 & 3.59 \\
\hline
\end{tabular}

The effectiveness of the production is achieved based on the relative amount of accomplished profit and total investing. The total investing incorporates investments into the production of farm objects and equipment. The effectiveness of the total production process in the observed case is not difficult to calculate since the production is intensive in control conditions and is realized in one production cycle. Realized effectiveness for the treatment fed with dietary addition of medicinal plants was $8.01 \%$ and $3.59 \%$ for the control treatment fed with the standard commercial dietary mixture.

Regarding our obtained results in this investigation, comparable research investigating the influence of natural alternatives to antibiotic drugs in poultry production has shown promising results. The investigation of Talpaz et al. (2013) demonstrates that the capacity to calculate the optimal density of chicken compound feed to optimize feeding margins offers a significant economic impact. According to the same study, in order to determine the optimal feed nutritional content, component costs, market meat costs, marketing, and availability of biological efficiency of chicken products must be considered. Our results have shown that the inclusion of dietary medicinal plants has good and positive influence on the chicken's diet, suggesting that a reduction in some nutrients in the dietary combination be considered. Studies have demonstrated that supplementing a basic meal with $1 \%$ mint leaves reduces feed cost $/ \mathrm{kg}$ of live body weight growth in broiler chickens (Puvača et al., 2020). Furthermore, the findings of 
other authors' assessments of the net profit in the economic research, revenue, and total cost revealed that a blend of dietary medicinal plants in the broilers diet had maximum profitability in comparison to diets lacking herbal ingredients.

\section{Conclusions}

Production effectiveness is fundamental principle and the foundation of rational business in a market economy, and it is increasingly becoming a need for production in our economy. A thorough examination of economic metrics reveals that the production is profitable. The realized production effectiveness makes $8.01 \%$ for the treatment fed with medicinal plants and 3.59\% for the control treatment. Regardless, all of the evidence offered supports the use of medicinal herbs in broiler meat production.

\section{Acknowledgements}

This research was funded by the Ministry for Education, Science and Technological Development of the Republic of Serbia.

\section{Conflict of interests}

The authors declare no conflict of interest.

\section{References}

1. Aćimović, M. G., Tešević, V. V., Smiljanić, K. T., Cvetković, M. T., Stanković, J. M., Kiprovski, B. M., \& Sikora, V. S. (2020). Hydrolates: By-products of essential oil distillation: Chemical composition, biological activity and potential uses. Advanced Technologies, 9(2), 54-70. https://doi.org/10.5937/savteh2002054A

2. Andleeb, S., Jamal, M., Bukhari, S. M. A. U. S., Sardar, S., \& Majid, M. (2020). Trends in Antimicrobial Use in Food Animals, Aquaculture and Hospital Waste. In M. Z. Hashmi (Ed.), Antibiotics and Antimicrobial Resistance Genes: Environmental Occurrence and Treatment Technologies (pp. 95-138). Springer International Publishing. https://doi.org/10.1007/978-3-030-40422-2_5

3. Baldi, G., Soglia, F., Laghi, L., Meluzzi, Adele, \& Petracci, M. (2021). The role of histidine dipeptides on postmortem acidification of broiler muscles with different energy metabolism. Poultry Science, 100(2), 1299-1307. https://doi.org/10.1016/j. psj.2020.11.032

4. Cardoso-Ugarte, G. A., \& Sosa-Morales, M. E. (2021). Essential Oils from Herbs and Spices as Natural Antioxidants: Diversity of Promising Food Applications in the past Decade. Food Reviews International, 0(0), 1-31. https://doi.org/10.1080/8 7559129.2021.1872084

5. Ćirić, M., Ignjatijević, S., \& Cvijanović, D. (2015). Research of honey consumers' behavior in province of Vojvodina. Economics of Agriculture, 62(3), 627-644. https://doi.org/10.5937/ekoPolj1503627C 
6. Croxton, K. L., García-Dastugue, S. J., Lambert, D. M., \& Rogers, D. S. (2001). The Supply Chain Management Processes. The International Journal of Logistics Management, 12(2), 13-36. https://doi.org/10.1108/09574090110806271

7. Guo, M., van Dam, K. H., Touhami, N. O., Nguyen, R., Delval, F., Jamieson, C., \& Shah, N. (2020). Multi-level system modelling of the resource-food-bioenergy nexus in the global south. Energy, 197, 117196. https://doi.org/10.1016/j. energy.2020.117196

8. Kuckertz, A., Brändle, L., Gaudig, A., Hinderer, S., Morales Reyes, C. A., Prochotta, A., Steinbrink, K. M., \& Berger, E. S. C. (2020). Startups in times of crisis - A rapid response to the COVID-19 pandemic. Journal of Business Venturing Insights, 13, e00169. https://doi.org/10.1016/j.jbvi.2020.e00169

9. Lovarelli, D., Bacenetti, J., \& Guarino, M. (2020). A review on dairy cattle farming: Is precision livestock farming the compromise for an environmental, economic and social sustainable production? Journal of Cleaner Production, 262, 121409. https:// doi.org/10.1016/j.jclepro.2020.121409

10. Misra, S., Pandey, P., \& Mishra, H. N. (2021). Novel approaches for co-encapsulation of probiotic bacteria with bioactive compounds, their health benefits and functional food product development: A review. Trends in Food Science \& Technology, 109, 340-351. https://doi.org/10.1016/j.tifs.2021.01.039

11. Popović, S., Kostadinović, L., Đuragić, O., Aćimović, M., Čabarkapa, I., Puvača, N., \& Pelić, D. L. (2018). Influence of medicinal plants mixtures (Artemisia absinthium, Thymus vulgaris, Menthae piperitae and Thymus serpyllum) in broilers nutrition on biochemical blood status. Journal of Agronomy, Technology and Engineering Management, 1(1), 91-98.

12. Puvača, N., Kostadinović, Lj., Popović, S., Lević, J., Ljubojević, D., Tufarelli, V., Jovanović, R., Tasić, T., Ikonić, P., \& Lukač, D. (2016). Proximate composition, cholesterol concentration and lipid oxidation of meat from chickens fed dietary spice addition (Allium sativum, Piper nigrum, Capsicum annuum). Animal Production Science, 56(11), 1920-1927. https://doi.org/10.1071/AN15115

13. Puvača, Nikola, Brkić, I., Jahić, M., Roljević Nikolić, S., Radović, G., Ivanišević, D., Đokić, M., Bošković, D., Ilić, D., Brkanlić, S., \& Prodanović, R. (2020). The Effect of Using Natural or Biotic Dietary Supplements in Poultry Nutrition on the Effectiveness of Meat Production. Sustainability, 12(11), 4373. https://doi. org/10.3390/su12114373

14. Puvača, Nikola, Čabarkapa, I., Bursić, V., Petrović, A., \& Aćimović, M. (2018). Antimicrobial, antioxidant and acaricidal properties of tea. Journal of Agronomy, Technology and Engineering Management, 1(1), 29-38.

15. Puvača, Nikola, \& de Llanos Frutos, R. (2021). Antimicrobial Resistance in Escherichia coli Strains Isolated from Humans and Pet Animals. Antibiotics, 10(1), 69. https://doi.org/10.3390/antibiotics 10010069 
16. Reisch, L., Eberle, U., \& Lorek, S. (2013). Sustainable food consumption: An overview of contemporary issues and policies. Sustainability: Science, Practice and Policy, 9(2), 7-25. https://doi.org/10.1080/15487733.2013.11908111

17. Talpaz, H., Cohen, M., Fancher, B., \& Halley, J. (2013). Applying complex models to poultry production in the future-Economics and biology. Poultry Science, 92(9), 2541-2549. https://doi.org/10.3382/ps.2012-02770

18. Tasić, S. (2018). Geographical and economic performance of organic agriculture and its impact on the stability of gastronomy tourism in Serbia. Oditor, 4(1), 38-51.

19. Woods, S. L., Rose, S. P., Whiting, I. M., Ionescu, C., Blanchard, A., \& Pirgozliev, V. (2020). The effect of feeding different sources and levels of selenium on growth performance and antioxidant status of broilers raised at two different temperatures. British Poultry Science, 61(6), 669-675. https://doi.org/10.1080/ 00071668.2020 .1782350 